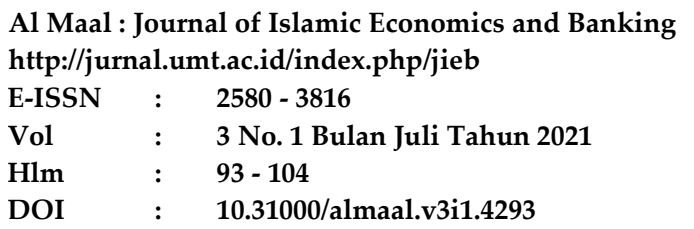

\title{
The Effectiveness of Zakat Disbursement by Amil Zakat Institutions in Indonesia
}

\author{
Efri Syamsul Bahri ${ }^{1 *}$, Indra Utama ${ }^{2}$, Zainal Arif ${ }^{3}$, Muhamad Zaedi $^{4}$, Ade Salamun ${ }^{5}$ \\ ${ }^{1}$ Prodi Akuntansi Syariah, Sekolah Tinggi Ekonomi Islam SEBI, Indonesia \\ ${ }^{2}$ Universitas Dehasen, Bengkulu, Indonesia \\ ${ }^{3}$ Prodi Perbankan Syariah, Universitas Muhammadiyah Tangerang, Indonesia \\ ${ }^{4}$ Fakultas Agama Islam Universitas Wiralodra, Indonesia \\ ${ }^{5}$ Prodi Pengembangan Masyarakat Islam, STID Mohammad Natsir, Indonesia \\ *efri.sb@sebi.ac.id
}

\section{ABSTRACT}

The Amil Zakat Institute (LAZ) is an institution licensed to assist the National Board of Zakat (Baznas) in collecting, distributing, and utilizing zakat. One of the main tasks of the LAZ is to distribute zakat to mustahiq in the Very Effective category. This study compares the effectiveness of zakat disbursement at the Amil Zakat institution. The effectiveness of the allocation-tocollection ratio (ACR) method was determined using Zakat core principles (ZCP). The objects used in this research are the financial statements of the National Zakat Institute, including LAZ IZI, LAZ Rumah Zakat, and LAZ Dewan Dakwah. Measurements were performed from 2015 to 2019. The results of the study found that the level of disbursement effectiveness from 2016 to 2019 was LAZ Dewan Dakwah ( $n=101 \%$ highly effective category), LAZ IZI ( $n=92 \%$ highly effective category) ), and LAZ Rumah Zakat ( $n=88 \%$ effective category). The implication is that the three LAZs have advantages in terms of their disbursement. Therefore, it is suggested to optimize the collection of zakat through LAZ. Therefore, the benefits of zakat are increasingly felt by mustahiq.

Keywords: Effectiveness; Disbursement; Zakat Core Principle; Amil Zakat Institution

\begin{abstract}
ABSTRAK
Lembaga Amil Zakat adalah lembaga yang memiliki izin untuk membantu Badan Zakat Nasional dalam mengumpulkan, mendistribusikan, dan memanfaatkan zakat. Salah satu tugas utama LAZ adalah menyalurkan zakat kepada mustahiq dalam kategori Sangat Efektif. Penelitian ini membandingkan efektivitas penyaluran zakat pada LAZ dengan menggunakan metode rasio allocation-to-collection ration yang mengacu pada Zakat Core Principle. Objek yang digunakan dalam penelitian ini adalah laporan keuangan LAZ Nasional yang meliputi LAZ IZI, LAZ Rumah Zakat, dan LAZ Dewan Dakwah. Pengukuran dilakukan dari tahun 2015 hingga 2019. Hasil kajian menemukan bahwa tingkat efektivitas dari tahun 2016 hingga 2019 adalah LAZ Dewan Dakwah ( $n=101 \%$ kategori sangat efektif), LAZ IZI ( $n=92 \%$ kategori sangat efektif), dan LAZ Rumah Zakat ( $n=88 \%$ kategori efektif). Implikasinya, ketiga LAZ tersebut memiliki keunggulan dalam hal pencairannya. Oleh karena itu, disarankan untuk mengoptimalkan penghimpunan zakat melalui LAZ. Oleh karena itu, manfaat zakat semakin dirasakan oleh mustahiq.
\end{abstract}

Kata kunci : Efektivitas; Penyaluran; Prinsip Inti Zakat; Lembaga Amil Zakat. 


\section{INTRODUCTION}

In the regulation of Law Number 23, the Year 2011, concerning Zakat Management, it is stated to assist the National Board of Zakat (Baznas) in implementing the collection, disbursement, and utilization of zakat, the community, can form the Amil Zakat Institution (LAZ). According to the National Zakat Statistics, the latest data, the number of LAZs in Indonesia has reached 68 LAZ consisting of 23 national LAZ, 12 provincial LAZ, and 33 district/city LAZ (Baznas, 2019).

Although LAZ is positioned to help Baznas, LAZ has a significant contribution in managing national zakat. The contribution of the LAZ can be shown from two aspects: the collection and disbursements of zakat. From the aspect of the collection, in 2018, LAZ nationally managed to collect zakat, including infaq/alms, amounting to IDR $3,634,332,619,382$. This shows that the performance of the zakat collection by the LAZ reached $44.77 \%$. The performance of zakat collection by LAZ far exceeds that of zakat management entities from government agencies.

From the aspect of disbursement of funds, nationally, it reached IDR $3,100,034,381,065$. LAZ's contribution to the disbursement of zakat reached a performance of $45.59 \%$. The performance of zakat disbursement by LAZ far exceeds zakat management entities from government agencies. The amount of zakat collection and disbursement is shown in the table below.

Table 1. Collection and Disbursement of Zakat in Indonesia in 2018

\begin{tabular}{|c|c|c|c|c|c|}
\hline \multirow{2}{*}{$\begin{array}{l}\text { Level of Zakat } \\
\text { Management } \\
\text { Entity }\end{array}$} & \multicolumn{2}{|l|}{ Collection } & \multicolumn{2}{|l|}{ Disbursement } & \multirow[b]{2}{*}{ Absorption } \\
\hline & $I D R$ & $\%$ & $I D R$ & $\%$ & \\
\hline Baznas & 206.374 .175 .575 & 2.54 & 235.664 .651 .030 & 3.47 & $83.77 \%$ \\
\hline Baznas Province & 552.209 .167 .922 & 6.80 & 462.230 .919 .380 & 6.80 & \\
\hline $\begin{array}{l}\text { Baznas } \\
\text { District/City }\end{array}$ & 3.171 .701 .720 .388 & 39.07 & 2.490 .478 .790 .649 & 36.62 & \\
\hline$L A Z$ & 3.634 .332 .619 .382 & 44.77 & 3.100 .034 .381 .065 & 45.59 & \\
\hline Zakat & 552.980 .000 .000 & 6.81 & 511.730 .391 .073 & 7.53 & Efektif \\
\hline $\begin{array}{l}\text { Management } \\
\text { Entity in } \\
\text { Institutional } \\
\text { Development }\end{array}$ & & & & & \\
\hline Total & 8.117.597.683.267 & 100.00 & 6.800 .139 .133 .196 & 100.00 & \\
\hline
\end{tabular}

Source: Baznas (2019)

According to Bayinah (2019), the LAZ's contribution is significant for national development. Nasrulloh (2019) argues that his contribution is very holistic to the sustainability of mustahiq's welfare. This is in line with the opinion of Qardhawi (2005), as explained by Wulansari and Setiawan 2014), that the role of zakat is to overcome other social problems. To optimize the role of LAZ, it is essential to evaluate the LAZ performance (Yuanta, 2013). Research results support this by Handriana (2016), who 
found that good performance can trust donors. Mustafa et al. (2013) describe, according to Mohammad (1990), the experience in Pakistan shows that zakat payers' trust has helped the survival of private zakat institutions.

One of the dimensions of the LAZ's core activities that need to be evaluated and maintained in trust is the effectiveness of the zakat distribution. This is explained by Ismail et al. (2018) in the Contextual Fikih of Zakat that zakat collected at zakat institutions must be distributed entirely within one year. Ismail et al. (2018) argue that zakat funds should not be deposited in amil accounts for more than one year on amil accounts for more than one year. Measuring the level of effectiveness at several LAZs is also a mandate of Law No.23 of 2011 concerning zakat management, which states that zakat management must be carried out effectively so that zakat is beneficial for realizing community welfare and poverty alleviation. Related to this distribution of zakat, Ahmed et al. (2017) argue that Sharia scholars are constantly checking the boundaries for the eight categories of zakat recipients to interact well with current conditions.

Of the 23 LAZs at the national level in Indonesia (Baznas, 2019), a comparative study on the effectiveness of zakat disbursement was carried out on three LAZs: LAZ Initiative Zakat Indonesia (IZI), LAZ Rumah Zakat, and LAZ Dewan Dakwah. LAZ IZI received appreciation from the Ministry of Religion as the Best LAZ in 2018 (Bahri et al., 2020). The study results by Pratama and Cahyono (2020) state that Rumah Zakat has increased productivity from 2010 to 2017. Jauhari (2016), LAZ Dewan Dakwah has advantages because it has a dai empowerment program in Indonesia's interior to support dawah's independence.

Therefore, this research aims to compare the effectiveness of zakat disbursement in the three operating nations: LAZ IZI, LAZ Rumah Zakat, and LAZ Dewan Dakwah. In previous studies, several researchers, e.g., Bahri et al. (2020), Bahri \& Arif (2020, Bahri \& Khumaini (2020), have measured the effectiveness of zakat disbursement on one LAZ object. In this study, three LAZ entities are compared. A comparative approach was performed to obtain an overview of the effectiveness of the zakat distribution for each entity and compare the measurement results. Thus, the results of this study illustrate the effectiveness of several entities that represent amil zakat institutions in Indonesia.

\section{LITERATURE REVIEW Definition of Zakat}

According to (Adnan and Bakar, 2009), zakat is generally understood as the third pillar of Islam. Hudayati and Tohirin 2010) argue that the position of zakat is as important as prayer. According to Yaacob et al. (2013), zakat means growing, increasing, and purifying. Riza (2019) clarifies, according to the opinion of Ibn Manzur (p.358) from the perspective of the language of zakat is the primary word (mașdar) of "zakā (اكز)" which means holy, blessing, growth, goodness, and praiseworthy.

Ismail et al. (2018) explain that zakat is a pillar of Islam with socio-economic features. This is in line with Qardhawi's (1993) opinion, which states that zakat is maaliyah ijtimaa'iyyah worship (worship of wealth which has a social dimension) Riyaldi (2017), states that zakat is a specific right in wealthy people's assets that must be 
distributed to those who are entitled to receive (asnaf) zakat. Yusuf and Derus (2013) explain that zakat is an obligation paid by rich people to poor people whose collection is liked collectively, such as the five daily prayers.

In the perspective of Sharia, zakat is an obligation that is ordered directly by Allah SWT in Alquran surah at-Taubah verse 103, because it can purify property from the rights of others, as a means of purifying oneself, fostering a sense of sharing, and prioritizing praying between the giver and recipient (Riwayati \& Hidayah, 2018). According to Wulansari and Setiawan (2014), zakat's obligation is also explained in Law number 23 of 2011 articles 1 and 2. It is explained that zakat is an asset that must be issued by a Muslim or a business entity to be given to those entitled to receive it following Islamic law.

\section{Disbursement of Zakat}

Bahri and Khumaini (2020) menyebutkan bahwa, menurut Kamus Besar Bahasa Indonesia (KBBI), state that, according to the Big Indonesian Dictionary (KBBI), disbursement is defined as a process, a method, an act of channeling. Indrawati (2016) explains that in the context of zakat, disbursement is a process, method, and action in disbursement zakat to mustahiq as a person who has the right to receive zakat. From the perspective of Sharia, this is contained in the Koran in the letter At-Taubah verse 60 . From a regulatory perspective, it states that zakat must be disbursed to mustahiq following Islamic law. Based on the explanation above, the beneficiary of zakat is mustahiq, consisting of eight asnaf: Fakir, Miskin, Amil, Muallaf, Riqob, Ghorimin, Ibnu sabil dan Fii sabilillah.

Zakat disbursement is a function of the LAZ as an intermediary function, namely, collecting zakat and paying zakat to mustahiq (Zadjuli et al., 2020). For this reason, Zadjuli et al. (2020) explained the importance of LAZ in maintaining the reputation and trust of muzaki to maintain its sustainability. Ahmed (2004) explains that a better reputation from an institution will make it easier to increase muzaki because it raises funds.

\section{Effectiveness of Zakat Disbursement}

Riza (2019) explains that according to the Big Indonesian Dictionary, the word effective means that it can produce results, comes into effect, there is an effect/consequence/effect. Furthermore, Bahri and Khumaini (2020) explain, according to Rifaí (2013) that word effectiveness has the meaning of the success of an activity or activity in achieving predetermined goals (goals). Susilowati and Setyorini (2018) argue that zakat disbursement is effective for zakat governance. Afif and Oktiadi (2018) argue that effectiveness is a measure of an organization's success or failure to achieve its goals and targets.

The benefits of measuring the effectiveness include improving the quality of the zakat management system (Rusydiana and Firmansyah, 2017) and identifying the risks of managing zakat (Dyarini, 2017). With the growing growth of zakat management entities in Indonesia, measuring effectiveness is essential for improving the quality of zakat management systems and controlling the risks. This is in line with the initial idea 
of compiling the core principle of Zakat related to risk management in zakat management (Triyani et al., 2018).

With the measurement of effectiveness, this can prevent the deposition of funds in amil accounts. This follows the explanation in the Contextual Fiqh of Zakat that zakat collected at zakat institutions must be distributed entirely within one year (Ismail et al., 2018). This is in line with the results of Yaacob et al. (2013), who recommend the need for supervision for program improvement and optimization of zakat distribution to mustahiq. This is supported by Mubtadi's (2019) opinion, which states that performance measurement is needed to ensure the institution's operation in achieving its objectives as a form of Islamic governance in zakat institutions. The research results of Muliati et al. (2020) also show that the accountability of amil zakat institutions and the distribution of productive zakat is essential in improving the welfare of zakat recipients as the primary goal of zakat.

According to Bahri and Khumaini (2020), measuring the effectiveness of zakat disbursement can use the allocation-to-collection ratio (ACR) formula adopted from the Zakat core principles. The measurement of the effectiveness of zakat disbursement aims to determine the position of the effectiveness level of the LAZ. As an illustration, based on the Zakat core principle, there are five categories of zakat disbursement effectiveness: 1. highly effective ACR $\geq 90$ percent), and 2. effective ACR reaches 70-89 percent, 3 . fairly effective ACR reaches 50-69 percent, 4. below expectation ACR reaches 20-49 percent, and 5. The ineffective ACR was <20 percent (Puskas, 2018).

\section{RESEARCH METHODS}

This study used a quantitative method with an allocation-to-collection ratio (ACR) ratio approach. This ratio was adopted from the Zakat core principle. Bahri and Khumaini (2020) explained that ACR is obtained by dividing the total funds for disbursement by the total funds raised. The ACR assessment category consists of five levels: 1 . The highly effective ACR was $\geq 90$ percent, 2. Effective ACR reaches 70-89 percent, 3. Fairly effective ACR reaches 50-69 percent, 4. Below expectation, ACR reaches 20-49 percent, and 5. Ineffective ACR was $<20$ percent (Puskas, 2018).

The object used in this research is a report on zakat disbursements of three LAZs: LAZ IZI, LAZ Rumah Zakat, and LAZ Dewan Dakwah. The three LAZs were purposively selected from the LAZ at the national level, and financial reports were published online on the institution's website. The reporting period was 2016-2019-data obtained through searches on the respective LAZ sites. The data were downloaded and processed according to ACR formula.

\section{RESULTS AND DISCUSSION Profile of the Amil Zakat Institution}

LAZ Initiative Zakat Indonesia was established on November 10, 2014. LAZ IZI results from a spin-off process from the Foundation for Justice and Care for the Ummah (PKPU). As stated on the LAZ IZI website page, this spin-off is motivated by a strong determination to build an authentic zakat management institution. Thus, LAZ IZI focuses 
on the management of zakat, infaq/alms, and other social-religious funds. LAZ IZI officially obtained an active license as LAZ on December 30, 2015. Ratification as LAZ is based on the decree of the Minister of Religion no. 423 of 2015. Zakat disbursement to mustahiq is packaged in the form of five excellent programs: IZI to Success, IZI to Smart, IZI to Fit, IZI to Faith, and IZI to Help.

LAZ Rumah Zakat (RZ) was initiated by Abi Syauqi on July 2, 1998. Initially, the name of the institution was Ummul Quro Social Wallet (DSUQ). The transformation process from DSUQ to Rumah Zakat occurred in 2003. This was marked by the issuance of the Decree of the Minister of Religion No. 157 on March 18, 2003, when the Rumah Zakat Indoensia DSUQ became the National Amil Zakat Institution. (Andriyanto, 2011; Bahri \& Arif, 2020)

The vision presented by Rumah Zakat is an international philanthropic institution based on professional empowerment. There are three missions carried out by Rumah Zakat, namely: (1) Taking an active role in building international philanthropic networks; (2) Facilitating community independence; and (3) Optimizing all aspects of resources through human excellence. The disbursement of zakat, infaq/alms to mustahiq is carried out through four empowerment programs: healthy smiles, champion smiles, independent smiles, and sustainable smiles. Four clumps of the program were packaged for integrated community development (ICD) empowerment.

LAZ Dewan Dakwah obtained an operational permit as LAZ through a decree of the Minister of Religion Number 407 on September 17, 2002. LAZ Dewan Dakwah was established by the Dewan Dakwah Foundation with the aim of collecting zakat and infaq/alms funds. The funds that have been collected are channeled to mustahiq in the form of various da'wah programs, including educational scholarships, preaching in the interior, community empowerment, humanity, and health.

The VISION carried by LAZ Dewan Dakwah is to become the leading zakat management institution with an emphasis on encouraging the improvement of the quality and disbursement of dakwah in Indonesia. Three missions were performed. First, increasing participation in da'wah and social care for the community through efforts to raise funds for Zakat, Infaq, Shadaqah and Waqf (ZISWAF) and other social funds, which are lawful and legal. Second, build yourself into an institution that is trustworthy, professional, transparent and easily accessible to the public. Third, it plays an active role in efforts to improve the quality and coverage of dakwah bil hal to the community.

\section{Collection and Disbursement of Zakat}

As LAZ, the three institutions, namely: LAZ IZI, LAZ Rumah Zakat, and LAZ Dewan Dakwah collect funds in the same type of funds: zakat and infakq/alms. Fundraising has become the focus of LAZ in fulfilling the requirements of LAZ at the national level. Based on the Decree of the Minister of Religion of the Republic of Indonesia Number 333 of 2015, every LAZ at the national level must have the ability to collect zakat, infaq/alms, and other socio-religious funds of at least IDR 50 billion in one year.. 
Fundraising is carried out by each LAZ using a variety of approaches. The types of funds collected by each LAZ are zakat and infaq/alms. The development of the number of zakat collections and infaq/alms for the three LAZs from 2016 to 2019 is shown in the table below.

Figure1. Comparison of Zakat Collection by LAZ IZI, LAZ Rumah Zakat, and LAZ Dewan Dakwah from 2016 to 2019 (IDR)

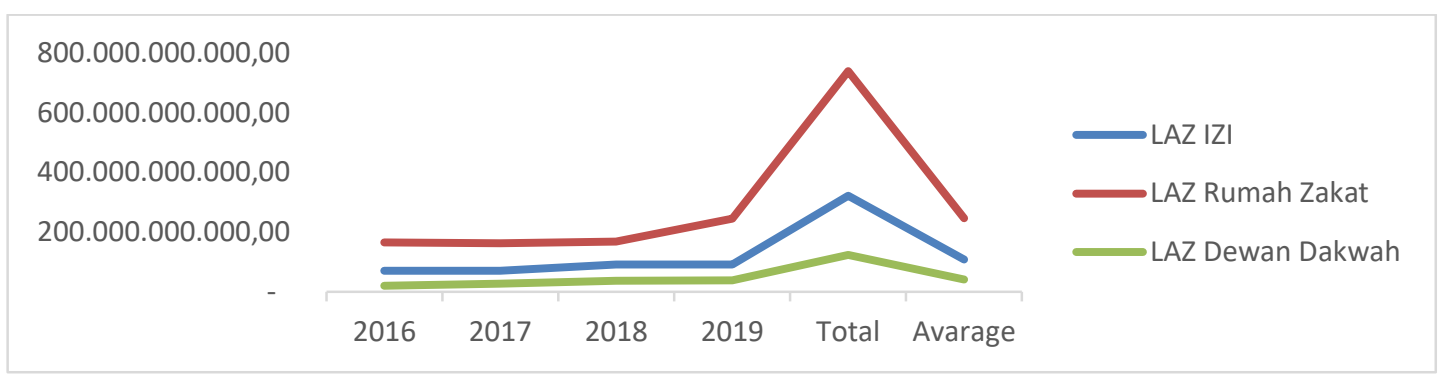

Source: Financial Statements LAZ IZI, LAZ Rumah Zakat, and LAZ Dewan Dakwah (processed)

Based on the picture above, the collection of zakat including infaq/alms that is carried out is LAZ Rumah Zakat IDR of $739,695,706,534$, LAZ IZI IDR $321,350,782,254$, and LAZ Dewan Dakwah IDR of 122,823,216,688. LAZ Rumah Zakat achieved the highest collection, with an average annual IDR of 246,565,235,511.33. Meanwhile, the achievement of fundraising by LAZ Dewan Dakwah has only reached an average IDR of 41,419,765,999 or still below IDR 50 billion, as the minimum fundraising limit. Therefore, it is important for the LAZ Dewan Dakwah to increase the capacity to collect zakat and infaq/alms funds to reach the minimum limit.

The funds that have been collected by the LAZ are then disbursed to mustahiq through various programs. The development of the number of zakat and infaq/alms disbursement for the three LAZs in the period 2026-2029 can be seen in the table below.

Figure 2. Comparations of Zakat Disbursement by LAZ IZI, LAZ Rumah Zakat, and LAZ Dewan Dakwah from 2016 to 2019 (IDR)

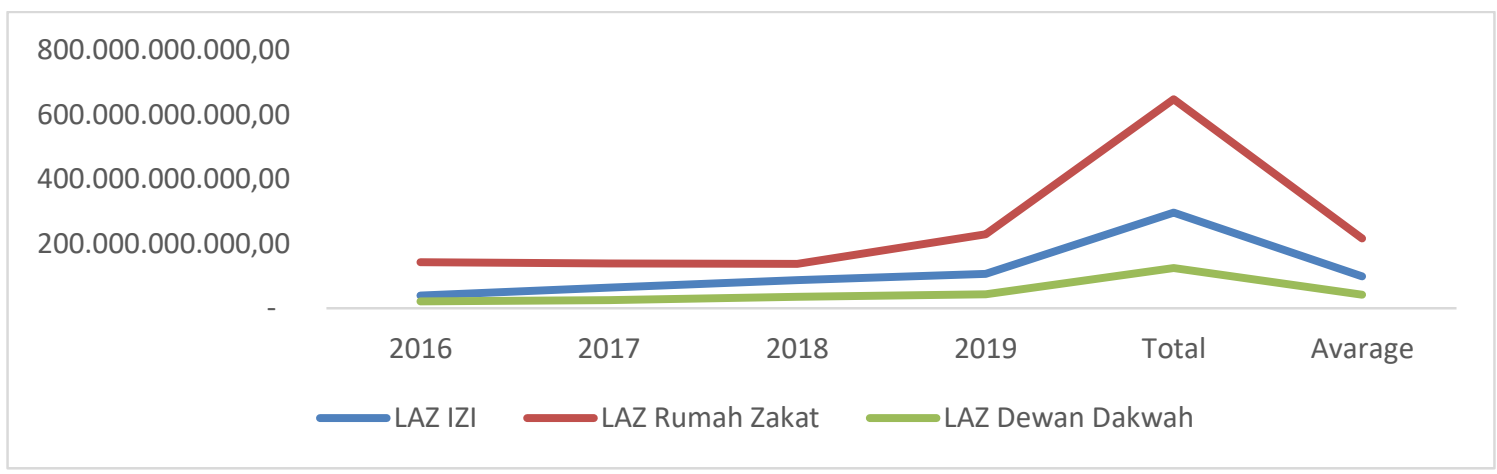

Source: Financial Statements LAZ IZI, LAZ Rumah Zakat, and LAZ Dewan Dakwah (processed) 
Based on the picture above, the disbursement of zakat including infaq/alms that is carried out is LAZ Rumah Zakat IDR of 648,580,920,929, LAZ IZI IDR of 296,628,136,022 and LAZ Dewan Dakwah IDR of 124,259,297,997. LAZ Rumah Zakat achieved the highest collection, with an average annual IDR of 216.193.640.309,67.

\section{Effectiveness of LAZ Disbursem ent}

The effectiveness of disbursement in this study can provide an overview of the LAZ's performance in one year and in the period from 2016 to 2019. The effectiveness of zakat disbursement in this study was measured on three LAZs: LAZ IZI, LAZ Rumah Zakat, and LAZ Dewan Dakwah. The three LAZs were selected purposively on the grounds that they are included in the LAZ category at the national level, financial reports are published online on the institutional website, the reporting period is 2016 to2019. Data were obtained through searches of the respective LAZ sites.

The level of effectiveness was measured using the allocation-to-collection ratio (ACR) formula. The ACR ratio was adopted from the Zakat core principle. The ACR ratio is obtained by dividing the total funds for disbursement by the total funds raised. The ACR measurements were then placed according to the assessment category with five levels: 1 . Highly effective ACR $\geq 90$ percent, 2 . Effective ACR reaches $70-89$ percent, 3 . Fairly effective ACR reaches 50-69 percent, 4. Below expectation (if ACR reaches 20-49 percent, and 5. Ineffective ACR $<20$ percent).

Based on the data that has been compiled, the comparative results of ACR measurements can be seen in the following table.

Table 2. Comparations for the collection and disbursement of Zakat by LAZ IZI, LAZ Rumah Zakat, and LAZ Dewan Dakwah from 2016 to 2019 (IDR)

\begin{tabular}{llll}
\hline Year & LAZ IZI & LAZ Rumah Zakat & LAZ Dewan Dakwah \\
\hline A. Collection of zakat & & \\
2016 & $69.973 .548 .817,00$ & $164.951 .765 .361,00$ & $20.263 .791 .687,00$ \\
2017 & $70.001 .255 .301,00$ & $162.533 .850 .851,00$ & $27.294 .606 .428,00$ \\
2018 & $90.469 .130 .362,00$ & $167.453 .081 .950,00$ & $36.850 .142 .702,00$ \\
2019 & $90.906 .847 .774,00$ & $244.757 .008 .372,00$ & $38.414 .675 .871,00$ \\
Total & $321.350 .782 .254,00$ & $739.695 .706 .534,00$ & $122.823 .216 .688,00$ \\
Avarage & $80.337 .695 .563,50$ & $184.923 .926 .633,50$ & $30.705 .804 .172,00$ \\
B. Disbursement of zakat & LAZ IZI & LAZ Rumah Zakat & LAZ Dewan Dakwah \\
Year & 38.816.945.100,00 & $142.516 .828 .665,00$ & $20.724 .144 .054,00$ \\
2016 & $63.855 .184 .404,00$ & $138.817 .306 .753,00$ & $25.124 .161 .439,00$ \\
2017 & $87.233 .760 .950,00$ & $137.665 .236 .474,00$ & $35.278 .204 .026,00$ \\
\hline
\end{tabular}


The Effectiveness of Zakat Disbursement by Amil Zakat Institutions in Indonesia

\begin{tabular}{|c|c|c|c|}
\hline 2019 & $106.722 .245 .568,00$ & $229.581 .549 .037,00$ & $43.132 .788 .478,00$ \\
\hline Total & 296.628.136.022,00 & $648.580 .920 .929,00$ & 124.259.297.997,00 \\
\hline Avarage & 74.157.034.005,50 & $162.145 .230 .232,25$ & $31.064 .824 .499,25$ \\
\hline \multicolumn{4}{|c|}{ C. Allocation-to-collection ratio (ACR) } \\
\hline 2016 & $55 \%$ & $86 \%$ & $102 \%$ \\
\hline 2017 & $91 \%$ & $85 \%$ & $92 \%$ \\
\hline 2018 & $96 \%$ & $82 \%$ & $96 \%$ \\
\hline 2019 & $117 \%$ & $94 \%$ & $112 \%$ \\
\hline $2016-2019$ & $92 \%$ & $88 \%$ & $101 \%$ \\
\hline
\end{tabular}

Based on the table above, the highest level of zakat disbursement effectiveness in the 2016-2019 period was achieved by the LAZ Dewan Dakwah ( $\mathrm{n}=101 \%$ highly effective category). Next, LAZ IZI ( $\mathrm{n}=92 \%$ highly effective category) and LAZ Rumah Zakat ( $\mathrm{n}=88 \%$ effective category). The results of measuring the effectiveness of zakat disbursement show that the LAZ Dewan Dakwah has a good capacity for disbursement zakat. Therefore, the number of fundraisers must increase. This will increase the benefits of zakat to mustahiq.

LAZ IZI has already been on track. This can be seen from the increase in the effectiveness of zakat disbursement every year, including 2016 (55\%), 2017 (91\%), 2018 (96\%), and 2019 (117\%). The implication is that the ACR average ratio in the 2016-2019 period can reach 92\%. LAZ Rumah Zakat is also on track. This is seen from the continuous increase in the effectiveness ratio every year, including 2016 (86\%), 2017 (85\%), $2018(82 \%)$, and $2019(94 \%)$. The implication is that the ACR average ratio in the 2016-2019 period can reach $88 \%$. The ACR ratio achieved by LAZ RUmah Zakta is still in the effective category. Therefore, to increase the ACR ratio, LAZ Rumah Zakat still needs to increase its zakat disbursement capacity.

\section{CONCLUSION}

The Amil Zakat Institution has made a major contribution in realizing the achievement of the goals of national zakat management in Indonesia. From the perspective of collecting zakat, LAZ contributed to $44.77 \%$. With regard to fund disbursements, LAZ contributed $45.59 \%$. This success needs to be continuously improved and replicated by zakat management entities, especially by zakat management entities from government agencies. Thus, the implementation of collection and disbursement of zakat through LAZ is important to be improved.

In this study, the effectiveness of zakat distribution was measured at three LAZ: LAZ IZI, LAZ Rumah Zakat, and LAZ Dewan Dakwah. Measurement of effectiveness uses an allocation to collection ratio (ACR) formula. The ACR formula is adopted from the Zakat core principle (ZCP). After the measurement results of each LAZ are obtained, the item ratio and effectiveness category are compared. The results of the study found that the value of distribution effectiveness in the 2016-2019 period was LAZ Dakwah 
Council ( $\mathrm{n}=101 \%$ for the category of highly effective), LAZ IZI ( $\mathrm{n}=92 \%$ for the category of highly effective), and LAZ Rumah Zakat ( $\mathrm{n}=88 \%$ for the category of effective). LAZ Dewan Dakwah achieved the highest effectiveness, followed by LAZ IZI and LAZ Rumah Zakat.

With high effectiveness values, the three LAZs have advantages in distribution. Therefore, it is suggested to optimize the collection of zakat through LAZ so that the zakat benefits are increasingly felt by mustahiq. Then, to maintain the effectiveness of zakat disbursement in the highly effective category, each LAZ should carry out regular monthly monitoring. This is expected to increase the benefits of zakat to mustahiq and increase the trust of muzaki.

The limitation of this study is that it does not take into account the amount of the beginning and ending balances. This is in accordance with the ACR formula in the core zakat principle. Therefore, it is necessary to modify ACR to accommodate the amounts of the beginning and ending balances. Data from LAZ Dewan Dakwah still includes the head office's collection and distribution and has not been consolidated from the regions. Further research is important to expand the scope of LAZ and zakat management entities from government agencies.

\section{REFERENCE}

Adnan, M. A., \& Bakar, N. B. A. (2009). Accounting treatment for corporate zakat: a critical review. International Journal of Islamic and Middle Eastern Finance and Management, 2(1), 32-45. https://doi.org/10.1108/17538390910946258

Afif, M., \& Oktiadi, S. (2018). Efektifitas distribusi dana zakat produktif dan kekuatan serta kelemahannya pada baznas magelang. Islamic Economics Journal, 4(2), 133. https://doi.org/10.21111/iej.v4i2.2962

Ahmed, B. O., Johari, F., \& Wahab, K. A. (2017). Identifying the poor and the needy among the beneficiaries of zakat need for a zakat-based poverty threshold in nigeria. International Journal of Social Economics, 44(4), 446-458. https://doi.org/10.1108/IJSE-09-2015-0234

Ahmed, H. (2004). Role of zakah and awqaf in poverty alleviation. In Islamic Research and Training Institute.

Andriyanto, I. (2011). Strategi pengelolaan zakat dalam pengentasan kemiskinan. Walisongo: Jurnal Penelitian Sosial Keagamaan, 19(1), 25. https://doi.org/10.21580/ws.19.1.211

Bahri, E. S., \& Arif, Z. (2020). Analisis efektivitas penyaluran zakat pada rumah zakat. Al Maal: Journal of Islamic Economics and Banking, 2(1), 13. https://doi.org/10.31000/almaal.v2i1.2642

Bahri, E. S., \& Khumaini, S. (2020). Analisis efektivitas penyaluran zakat pada badan amil zakat nasional. Al Maal: Journal of Islamic Economics and Banking, 1(2). https://doi.org/10.31000/almaal.v1i2.1878 
The Effectiveness of Zakat Disbursement by Amil Zakat Institutions in Indonesia

Bahri, E. S., Mizan, M., Aslam, M., \& Muhammad, A. (2020). Analysis of the effectiveness of zakat distribution at the amil zakat institution initiative zakat indonesia (laz izi). 23. https://doi.org/10.4108/eai.26-9-2020.2302947

Bayinah, A. N. (2019). Implementasi zakat sebagai pengurang penghasilan kena pajak. Jurnal Akuntansi Dan Keuangan Islam, 3(1), 83-98. https://doi.org/10.35836/jakis.v3i1.43

Baznas. (2019). Statistk zakat nasional 2018. In Baznas. BAZNAS.

Dyarini, S. J. (2017). Manajemen risiko pengelolaan zakat. Ikhraith-Humaniora, 1(2), 45-52. https://media.neliti.com/media/publications/226392-manajemen-risikopengelolaan-zakat-69d44100.pdf

Handriana, T. (2016). Analysis of donors' trust and relationship commitment in lembaga amil zakat in Indonesia. Journal of Economics, Business and Accountancy Ventura, 19(1), 59. https://doi.org/10.14414/jebav.v19i1.529

Hudayati, A., \& Tohirin, A. (2010). Management of zakah : centralised vs decentralised approach. Seventh International Conference - The Tawhidi Epistemology: Zakat and Waqf Economy, Bangi 2010, 351-374.

Indrawati, R. (2016). Evaluasi penerapan undangu-undang pengelolaan zakat dan akuntansi zakat (psak 109) pada baznas provinsi jatim. Jurnal Akuntansi UNESA, $4(2), 1-28$.

Jauhari, T. (2016). Customer satisfaction lembaga-lembaga dakwah. Jurnal Ilmu Dakwah Dan Pengembangan Komunitas, XI(1), 130-152. https://doi.org/10.24042/bu.v11i1.4797

Mubtadi, N. A. (2019). Analysis of islamic accountability and islamic governance in zakat institution. Hasanuddin Economics and Business Review, 3(1), 1. https://doi.org/10.26487/hebr.v3i1.1544

Muliati, Mayapada, A. G., Debriyanto, \& Halwi, M. D. (2020). The accountability and distribution of productive zakat in improving the welfare of zakat recipients. Proceedings of the International Conference on Community Development (ICCD 2020), 477(Iccd), 481-485. https://doi.org/10.2991/assehr.k.201017.106

Mustafa, M. O. A. (2013). Antecedents of zakat payers' trust in an emerging zakat sector: An exploratory study. Journal of Islamic Accounting and Business Research, 4(1), 4-25. https://doi.org/10.1108/17590811311314267

Nasrulloh. (2019). Filantropi islam: praktek dan kontribusinya terhadap ketercapaian sustainable development goals (sdgs). Annual Conference for Muslim Scholars, 364-375.

Puskas. (2018). Outlook zakat indonesia. https://www.puskasbaznas.com/publications/books/627-outlook-zakat-indonesia2018

Riwayati, S., \& Hidayah, N. B. (2018). Zakat dalam telaan qs. at-taubah:103 (penafsiran enam kitab). Al Furqan: Jurnal Ilmu Al Quran Dan Tafsir, 1(2), 77 - 
Efri Syamsul Bahri, Indra Utama, Zainal Arif, Muhamad Zaedi, \& Ade Salamun

91-77 - 91. http://ejournal.iai-tabah.ac.id/index.php/Alfurqon/article/view/287

Riyaldi, M. H. (2017). Kedudukan dan prinsip pembagian zakat dalam mengatasi permasalahan kemiskinan (analisis pandangan yusuf qardhawi). Jurnal Perspektif Ekonomi Darussalam, 3(1), 17-27. https://doi.org/10.24815/jped.v3i1.6989

Riza, M. S. (2019). Analisis efektivitas distribusi zakat produktif dalam meningkatkan kesejahteraan mustahik (studi kantor cabang rumah zakat sumatera utara). ATTAWASSUTH: Jurnal Ekonomi Islam, 4(1), 137. https://doi.org/10.30821/ajei.v4i1.4090

Rusydiana, A. S., \& Firmansyah, I. (2017). Prioritizing zakat core principles criteria. Esensi: Jurnal Bisnis Dan Manajemen, 7(2), 277-302. https://doi.org/10.15408/ess.v7i2.5275

Satori Ismail, A., Farid Mas'udi, M., Bahri, E. S., Halim, I., Tajang, M. N., Qasim, F., Hambali, A., \& Erianton, P. (2018). Fikih zakat kontekstual indonesia.

Susilowati, D., \& Setyorini, C. T. (2018). Efektivitas tata kelola dana zakat. Jurnal Akuntansi Multiparadigma, 9(2), 346-364. https://doi.org/10.18202/jamal.2018.04.9021

Triyani, N., Beik, I. S., \& Baga, L. M. (2018). Manajemen risiko pada badan amil zakat nasional (baznas). Al-Muzara'ah, 5(2), 107-124. https://doi.org/10.29244/jam.5.2.107-124

Wulansari, S. D., \& Setiawan, A. H. (2014). Analisis peranan dana zakat produktif terhadap perkembangan usaha mikro mustahik (penerima zakat) (studi kasus rumah zakat kota semarang). Diponegoro Journal of Economics, 3(1), 1-15. http://ejournal-s1.undip.ac.id/index.php/jme

Yaacob, A. C., Mohamed, S., Daut, A., Ismail, N., \& Don, M. A. M. (2013). Zakat Ddsbursement via capital assistance : a case study of Majlis agama islam johor. Journal of Emerging Economies and Islamic Research, 1(2), 1-19. https://doi.org/10.1088/1751-8113/44/8/085201

Yuanta, I. (2013). Penilaian kinerja lembaga amil zakat dengan pendekatan indonesia madnificence of zakat. Skripsi, 53(9), 1689-1699.

Yusuf, M. B. O., \& Derus, A. M. (2013). Measurement model of corporate zakat collection in malaysia: a test of diffusion of innovation theory. Humanomics, 29(1), 61-74. https://doi.org/10.1108/08288661311299321

Zadjuli, S. I., Shofawati, A., \& Muryani. (2020). Implementing good corporate governance in zakat institution. Bussecon Review of Social Sciences (2687-2285), 2(1), 27-37. https://doi.org/10.36096/brss.v2i1.158 